\title{
Statistical Distribution and Spatio-Temporal Variation of Nutrients in Lower Danube River Waters Between km 375 - km 175 in Relation to Hydrological Regime
}

\author{
VIOLETA-MONICA RADU ${ }^{1,2}$, PETRA IONESCU ${ }^{1,2 *}$ GYORGY DEAK ${ }^{1 *}$, ELENA DIACU ${ }^{2}$, \\ IRINA-ELENA CIOBOTARU ${ }^{1}$, ECATERINA MARCU ${ }^{1}$, MARIANA PIPIRIGEANU ${ }^{1}$ \\ ${ }^{1}$ National Institute for Research and Development in Environmental Protection, 294 Splaiul Independentei, 06003, \\ Bucharest, Romania \\ ${ }^{2}$ University Politehnica of Bucharest, Faculty of Applied Chemistry and Materials Science, 1-7 Polizu Str., 011061, \\ Bucharest, Romania
}

Abstract: Nutrient pollution, a growing problem for most European river basins, is a priority challenge in the Danube River Basin, a river that interconnects freshwater with the marine environment. The nutrient content of the Lower Danube waters in a river area where hydro-technical works to improve navigation conditions were carried out, respectively between $\mathrm{km} 375$ and $\mathrm{km} 175$, was evaluated in conection with other water quality parameters and with the hydrological regime. This paper is based on the data obtained during the period 2011-2017 on water samples taken from 10 sampling sections, and the following parameters were investigated: $\mathrm{pH}$, ammonia nitrogen - $\mathrm{NH}_{4}-\mathrm{N}$, nitrites - $\mathrm{NO}_{2}-\mathrm{N}$, nitrates - $\mathrm{NO}_{3}-\mathrm{N}$, total nitrogen - TN, orthophosphates - $\mathrm{PO}_{4}-\mathrm{P}$, total phosphorus $T P$, Chlorophyll $a-C h l$ ' $a$ ', all of which are correlated with water flow - $Q$. The results showed $a$ significant correlation between the nutrients content, Chl 'a', and water flow, taking into account both the anthropic and climatic pressures on the aquatic ecosystem and the impact of the water body loads on the Black Sea coastal zone.

Keywords: Danube River, water quality, nutrients, Chlorophyll a, statistical analysis

\section{Introduction}

Rivers pollution with nutrients is one of the most widespread human impacts on water resources, the water quality being affected both by the magnitude and the impact of anthropogenic activities and by the climate change [1-5].

Waste water resulting from urban, industrial and agricultural activities is the source of most nutrients that stimulate excessive algal growth [6-9]. The development of algae can physically change the structure of habitats, can lower oxygen concentration and may increase the $\mathrm{pH}$ of water, causing a negative impact on aquatic ecosystems [10-12]. Over time, high levels of nutrients have reduced the number of sensitive species of fishis, algae developed under high nutrient conditions, typically producing toxins that affect drinking water as well as aquatic biodiversity [13-17].

In recent decades, studies have increasingly been focusing on the nutrients from rivers that cause major problems that seriously affect ecosystem services and human wellbeing, nutrient pollution being a priority challenge also in the Danube River Basin [18-20]. According to the management plan developed by the ICPDR, about $65 \%$ of the length of the Danube River was classified at risk due to nutrient pollution [21, 22]. In addition, nitrogen and phosphorus causes eutrophication in the NorthWest Black Sea area, and it is known that the Black Sea is one of the largest semi-enclosed marine basins on earth where rivers discharge can be evaluated [23-25].

The Danube River Basin is recognized as the world's largest hydrographic basin, with borders with 19 industrialized countries, the Danube River being the second longest river in Europe after the Volga $[26,27]$. The lower course of the Danube River represents about $30 \%$ of its length and crosses

$\overline{\text { *email : petraionescu2012@yahoo.ro,dkrcontrol@yahoo.com }}$ 
Romania from Bazias to Sulina on a length of $1075 \mathrm{~km}$, being the most important surface water in Romania and one of the most important rivers that flow into the Black Sea [21, 28]. More than 80 million people live in this basin, many of them depending on the Danube for potable water, energy production, agriculture and transport. Its ecological diversity, ranging from plant and animal species to critical habitats, is also highly valued.

Hence, in this study, the content of nutrients in the Lower Danube, Calarasi-Braila section $(\mathrm{km} 375$ - $\mathrm{km}$ 175), was evaluated during the period 2011-2017, during which time there were works to improve the navigation conditions, being applied the statistical evaluation methods.

\section{Materials and methods}

The monitoring sites are located along the lower area of the Danube River (fig. 1), between

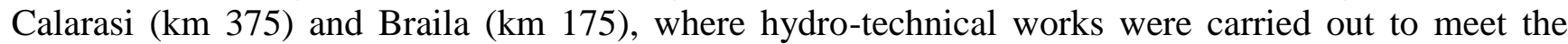
recommendations of the Danube Commission to maintain minimum navigation water depths during dry seasons [29]. Hydro-technical works included dredging, embankments and construction of bottom sills.

For environmental protection purposes, during the entire construction period, as well as before and after it, National Institute for Research and Development in Environmental Protection (INCDPM) performed the evolution of the environmental factors state in the intensive monitoring program. Innovative integrated monitoring systems were designed and used for identifying the possible impact of the constructions and to develop timely alternative solutions to intervene for reducing and controlling the foreseen risks.

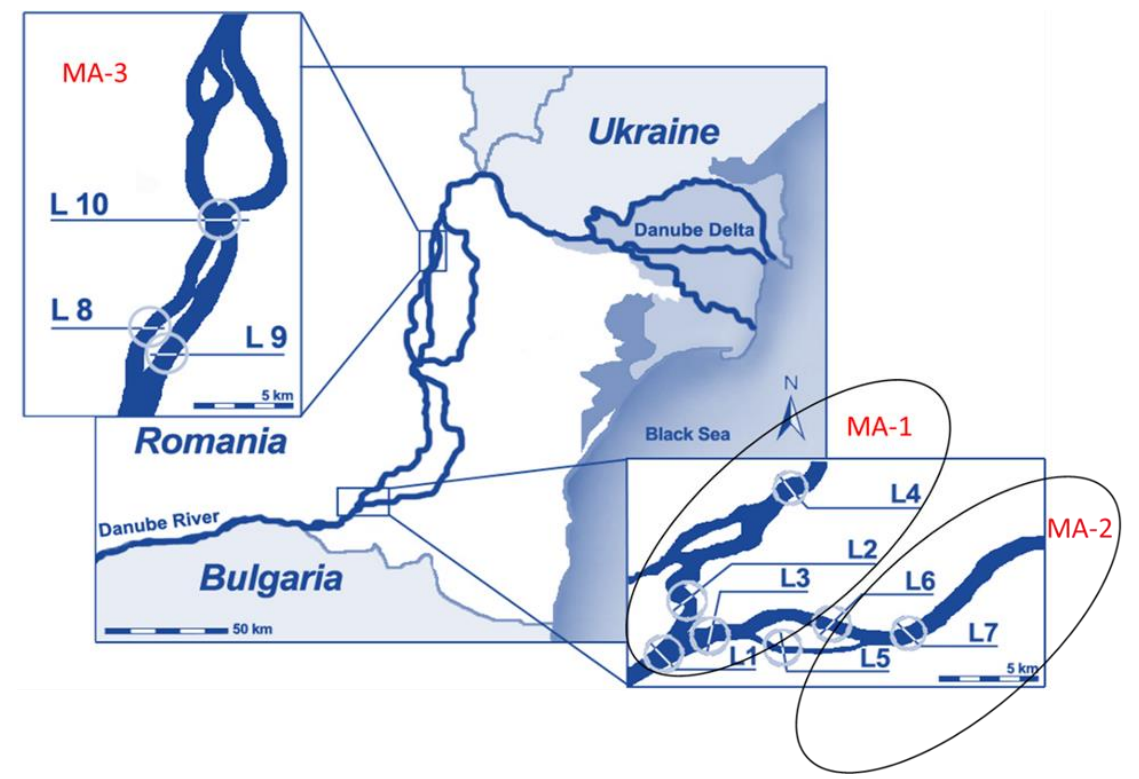

Figure 1. Sampling locations on the Lower Danube section [30]

For this purpose, the water samples were collected about 1500 of from 10 sampling locations situated in the Lower Danube River area (Table 1 and Figure 1), and the following indicators were monitored: $p \mathrm{H}$, ammonia nitrogen - $\mathrm{NH}_{4}-\mathrm{N}$, nitrites - $\mathrm{NO}_{2}-\mathrm{N}$, nitrates - $\mathrm{NO}_{3}-\mathrm{N}$, total nitrogen - $\mathrm{TN}$, orthophosphates - $\mathrm{PO}_{4}-\mathrm{P}$, total phosphorus - TP, Chlorophyll a - Chl 'a' and water flow - Q. 
Table 1

Water sampling locations

\begin{tabular}{|c|c|c|c|c|}
\hline \multirow{2}{*}{ Monitoring area } & \multirow{2}{*}{ Location } & \multirow{2}{*}{$\begin{array}{c}\text { Length } \\
(\mathbf{k m})\end{array}$} & \multicolumn{2}{|c|}{ Geographical coordinates } \\
\hline & & & longitude & latitude \\
\hline \multirow{4}{*}{$\begin{array}{c}\text { MA-1 } \\
\text { (Bala Area) }\end{array}$} & L1 & 347 & \multirow{4}{*}{$27^{\circ} 34^{\prime} 9.549^{\prime \prime}$} & \multirow{4}{*}{$44^{\circ} 11^{\prime} 24.35^{\prime \prime}$} \\
\hline & $\mathrm{L} 2$ & 345 & & \\
\hline & L3 & 344 & & \\
\hline & L4 & 343 & & \\
\hline \multirow{3}{*}{$\begin{array}{c}\text { MA-2 } \\
\text { (Epurasu Island) }\end{array}$} & L5 & 340 & \multirow{3}{*}{$27^{\circ} 37^{\prime} 2.349^{\prime \prime}$} & \multirow{3}{*}{$44^{\circ} 11^{\prime} 59.10^{\prime \prime}$} \\
\hline & L6 & 341 & & \\
\hline & L7 & 334 & & \\
\hline \multirow{3}{*}{$\begin{array}{c}\text { MA-3 } \\
\text { (Lupu Island) }\end{array}$} & L8 & 197 & \multirow{3}{*}{$27^{\circ} 54^{\prime} 27.93^{\prime \prime}$} & \multirow{3}{*}{$45^{\circ} 4^{\prime} 0.316^{\prime \prime}$} \\
\hline & L9 & 196 & & \\
\hline & L10 & 195 & & \\
\hline
\end{tabular}

The water samples were taken monthly during the hydro-technical construction period (September 2011 - September 2015) and half-yearly in the post-construction period (December 2015 - December 2017), at three water depths $(0.5,1.5$ and $3 \mathrm{~m})$ from 3 zones (left bank, right bank and river course). During the sampling campaigns, each water sample was collected directly from the river into a polyethylene container of 5 liters, and was transported directly to the laboratory of analysis, and stored at $4{ }^{0} \mathrm{C}$. All reagents used in this study were of analytical quality, solutions were prepared with double distilled water, and the determinations were performed according to standards in force. The acuracy of experimental data was ensured by periodical testing with references materials for water. All indicators were analyzed in accordance with European standards, and water flow was calculated in base of the level measurements on site.

Further information regarding the sampling areas and the quality indicators may be accessed on the monitoring project homepage http://www.afdj.ro/en/content/romomed.

At the complex database obtained from the integrated monitoring program, statistical evaluation methods were applied using the principal component analysis (PCA) and cluster analysis (CA), methods that facilitate the problem of interpreting the large number of data, generating useful and reliable information on the state of water quality. Also, has been achieved a spatial-temporal evaluation of monitored indicators, and their distribution and their clasification into quality classes according to M.O. 161/2006 and WFD (Water Framework Directive) [31, 32].

\section{Results and discussions}

To obtain information regarding the central tendency and distribution of each elements in the studied area, multivariate statistical analysis methods were applied to the data obtained during the monitoring program using the statistical software package JMP 10.

Table 2 presents a descriptive analysis of the elements concentration using several variables: minimum, median, maximum, mean, standard deviation, standard error mean and reference values according to the applicable legislation.

The results showed that the all parameters have recorded values over the normal values from the national legislation in force.

Principal Component Analysis method was performed to reduce the dimensionality of the data set using a matrix composed of the concentrations obtained for each element.

Table 2

STATISTICAL ANALYSIS OF PARAMETERS IN WATER

\begin{tabular}{cccccccccc}
\hline $\begin{array}{c}\text { Variables } \\
\text { Parameter }\end{array}$ & $\mathbf{p H}$ & $\mathbf{N H}_{4}-\mathbf{N}$ & $\mathbf{N O}_{2}-\mathbf{N}$ & $\mathbf{N O}_{3}-\mathbf{N}$ & $\mathbf{T N}$ & $\mathbf{P O}$-P & TP & $\mathbf{C h l}^{\prime} \mathbf{a}^{\prime}$ & $\mathbf{Q}$ \\
\hline Min & 7.16 & 0.01 & 0.001 & 0.02 & 0.13 & 0.007 & 0.02 & 0 & 5 \\
Median & 8.19 & 0.05 & 0.017 & 0.78 & 1.63 & 0.05 & 0.10 & 3.27 & 2613 \\
\hline
\end{tabular}




\begin{tabular}{ccccccccccc}
\hline Max & 8.64 & 0.68 & 0.06 & 1.88 & 3.42 & 0.21 & 0.68 & 49.75 & 11200 \\
Mean & 8.09 & 0.09 & 0.02 & 0.77 & 1.59 & 0.05 & 0.10 & 5.09 & 2905 \\
St Dev & 0.25 & 0.11 & 0.01 & 0.32 & 0.51 & 0.02 & 0.05 & 5.07 & 2002 \\
St Err Mean & 0.006 & 0.002 & 0.0002 & 0.008 & 0.012 & 0.0004 & 0.001 & 0.125 & 49 \\
90 \% & 8.35 & 0.29 & 0.036 & 1.18 & 2.16 & 0.07 & 0.13 & 11.85 & 5734 \\
$\mathbf{1 0} \%$ & 7.69 & 0.02 & 0.010 & 0.36 & 0.87 & 0.03 & 0.07 & 1.18 & 453 \\
Normal values* & $6.5-8.5$ & 0.4 & 0.01 & 1 & 1.5 & 0.1 & 0.15 & 25 & - \\
\hline
\end{tabular}

Table 3 shows the Pearson correlation coefficients between the concentrations of parameters. Pearson correlation coefficients for concentrations of nutrients from the water samples showed a direct relationship between elements. As it can be seen, the group of nutrients is strongly interrelated with Pearson factors predominantly greater than 0.5 . The $\mathrm{Chl}$ ' $\mathrm{a}$ ', $p \mathrm{H}$ and $\mathrm{Q}$ for the monitored section, appear to be uncorrelated with the evolution of nutrients concentrations. Between the nutrients linear correlations were established. The increase of the nutrients content with the water flow leads to a cumulative effect of the share of diffuse pollution (increases with water flow) with dilution. There is a lack of linear correlations of $\mathrm{Chl}$ ' $\mathrm{a}$ ' with the nutrients $\left(\mathrm{NH}_{4}-\mathrm{N}, \mathrm{NO}_{2}-\mathrm{N}, \mathrm{NO}_{3}-\mathrm{N}, \mathrm{TN}, \mathrm{PO}_{4}-\mathrm{P}, \mathrm{TP}\right)$ can be attributed to the gap between increased nutrient concentrations and algal growth. Also, the annual evolution of Chl ' $\mathrm{a}$ ' concentrations is strongly influenced by seasonal changes and local hydrological conditions, while nutrient levels are largely dependent on rainfall (due to soil leaching phenomena), anthropic discharge rate versus flow rate (eg. sewage treatment plants of municipal wastewater) between abiotic and biotic forms (eg. sediment intake and absorption).

Table 3. Pearson correlation coefficients among the water parameters

\begin{tabular}{|c|c|c|c|c|c|c|c|c|c|}
\hline & $\mathrm{NH}_{4}-\mathrm{N}$ & $\mathrm{NO}_{2}-\mathrm{N}$ & $\mathrm{NO}_{3}-\mathrm{N}$ & TN & $\mathrm{PO}_{4}-\mathrm{P}$ & TP & Chl, a' & $\mathrm{pH}$ & Q \\
\hline $\mathrm{NH}_{4}-\mathrm{N}$ & 1.0000 & & & & & & & & \\
\hline $\mathrm{NO}_{2}-\mathrm{N}$ & 0.3954 & 1.0000 & & & & & & & \\
\hline $\mathrm{NO}_{3}-\mathrm{N}$ & -0.3613 & -0.0808 & 1.0000 & & & & & & \\
\hline TN & -0.4070 & -0.1044 & 0.7664 & 1.0000 & & & & & \\
\hline $\mathrm{PO}_{4}-\mathrm{P}$ & -0.4439 & -0.2040 & 0.4326 & 0.5387 & 1.0000 & & & & \\
\hline TP & -0.2860 & -0.1445 & 0.2919 & 0.4050 & 0.6089 & 1.0000 & & & \\
\hline Chl , a' & -0.1809 & -0.2570 & -0.1101 & -0.0040 & -0.0846 & 0.0009 & 1.0000 & & \\
\hline $\mathrm{pH}$ & -0.5960 & -0.3156 & 0.3088 & 0.4019 & 0.4800 & 0.2062 & 0.1535 & 1.0000 & \\
\hline Q & -0.1240 & -0.0165 & 0.2951 & 0.2991 & 0.1956 & 0.1989 & 0.0608 & 0.0637 & 1.0000 \\
\hline
\end{tabular}

Table 4 contains selected significant loading values for the first 3 Principal Components (PC). The results of the loading matrix on the principal components showed that the first component comprised the variability of nutrients from data sets, the second component took over the variability of $\mathrm{NO}_{2}-\mathrm{N}_{\text {, }}$ the third component was associated with $\mathrm{Chl}$ ' $\mathrm{a}$ ' and Q as main constituents. 
Table 4

LOADING MATRIX

\begin{tabular}{|lllll|}
\hline Parameters & PC1 & PC2 & C3 & PC4 \\
\hline $\mathrm{TN}$ & 0.8023 & & & \\
$\mathrm{PO}_{4}-\mathrm{P}$ & 0.7883 & & & \\
$\mathrm{NO}_{3}-\mathrm{N}$ & 0.7178 & & & \\
$\mathrm{pH}$ & 0.6767 & & & 0.6722 \\
$\mathrm{TP}$ & 0.6159 & & & 0.5266 \\
$\mathrm{NO}_{2}-\mathrm{N}$ & & 0.6446 & & \\
$\mathrm{Q}$ & & & 0.7419 & \\
$\mathrm{NH}_{4}-\mathrm{N}$ & -0.7155 & & & \\
$\mathrm{Ch} 1 \mathrm{a}$ & & -0.6621 & 0.5338 & \\
\hline
\end{tabular}

Figure 2 shows the eigenvalues associated with the principal components and the percentage of variability accounted by each PC.

\begin{tabular}{|c|c|c|c|c|c|c|c|}
\hline Number & Eigenvalue & Percent & $\begin{array}{lllll}20 & 40 & 60 & 80\end{array}$ & Cum Percent & ChiSquare & DF & Prob $>$ ChiSq \\
\hline 1 & 3.4116 & 37.907 & & 37.907 & 5053.21 & 35.471 & $<.0001^{\star}$ \\
\hline 2 & 1.4958 & 16.620 & & 54.526 & 2333.12 & 32.271 & $<.0001^{\star}$ \\
\hline 3 & 1.0031 & 11.145 & & 65.671 & 1531.03 & 25.974 & $<.0001^{*}$ \\
\hline 4 & 0.8801 & 9.779 & & 75.451 & 1163.01 & 19.770 & $<.0001^{*}$ \\
\hline 5 & 0.6742 & 7.492 & & 82.942 & 784.439 & 14.504 & $<.0001^{*}$ \\
\hline 6 & 0.6256 & 6.951 & & 89.893 & 550.884 & 9.531 & $<.0001^{*}$ \\
\hline 7 & 0.4116 & 4.574 & & 94.467 & 189.794 & 5.737 & $<.0001^{*}$ \\
\hline 8 & 0.2894 & 3.216 & & 97.682 & 44.042 & 1.941 & $<.0001^{*}$ \\
\hline 9 & 0.2086 & 2.318 & & 100.000 & 0.000 & . & . \\
\hline
\end{tabular}

Figure 2. Eigenvalues and percentage of data variability accounted by each PC

The first principal component represents $37.91 \%$ from the variability of the entire data set, the second principal component supplemented by $16.62 \%$ the coverage of the original variance, the third principal component contributed with $11.15 \%$ and fourth principal component contributed with $9.78 \%$. This fact indicated that the first component collected much of the information from the samples, which contained elements from the common source of the river. All the fourth principle components accounted for approximately $75.46 \%$ of the entire variability of the data set, highlighting the major trends of the monitored ecosystem. The relative slow decay rate of the variability contribution of each individual PC may be another indication of the mostly uncorrelated evolutions of the monitored indicators caused by a high degree of heterogeneity.

For a more detailed assessment of the relationship between parameters, Cluster Analysis (CA) has been used. The results are illustrated by a hierarchical dendrogram as shown in figure 3. It is known that as value on the group of distances is lower, the more important the association is.

Depending on the degree of association between parameters, three distinct clusters could be identified (fig. 3), as follows: in the first group an association of nutrients can be observed, both in reduced and higher oxidation forms, the second group formed by $\mathrm{Chl}$ ' $\mathrm{a}$ ' and $\mathrm{pH}$, and the third group shows the overall association of the monitored indicators with the water flow. 


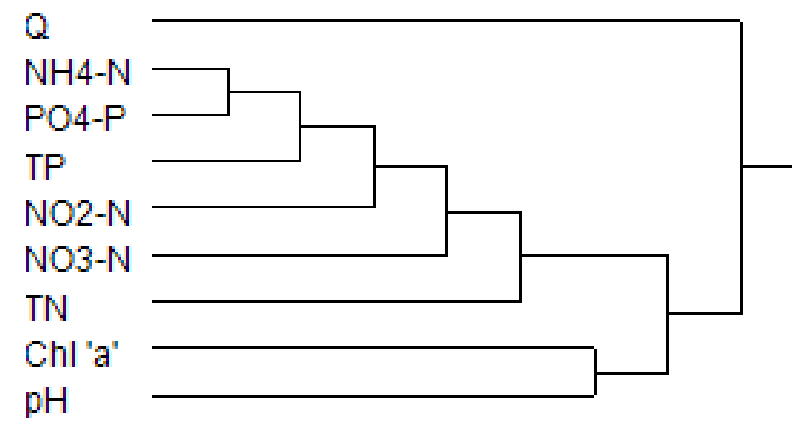

Figure 3. Dendrogram of parameters in CA method

From the comparison of the average values with the limits prescribed in M.O. 161/2006 [26] (fig. 4 and figure 5), the following quality items result: $\mathrm{NH}_{4}-\mathrm{N}, \mathrm{NO}_{3}-\mathrm{N}$ and $\mathrm{TN}$ fall into classes I-II, $\mathrm{NO}_{2}-\mathrm{N}$ fall in class I-III, $\mathrm{PO}_{4}-\mathrm{P}$ and TP fall in class $\mathrm{I}$, Chl ' $\mathrm{a}$ ' fall into class I and $\mathrm{pH}$ also fall into class I. Regarding sources, agriculture and urban water management are responsible for most nutrient emissions, for nitrogen, underground water (base flow) is the most important diffuse way, and for phosphorus, urban flow and soil erosion generate the highest emissions
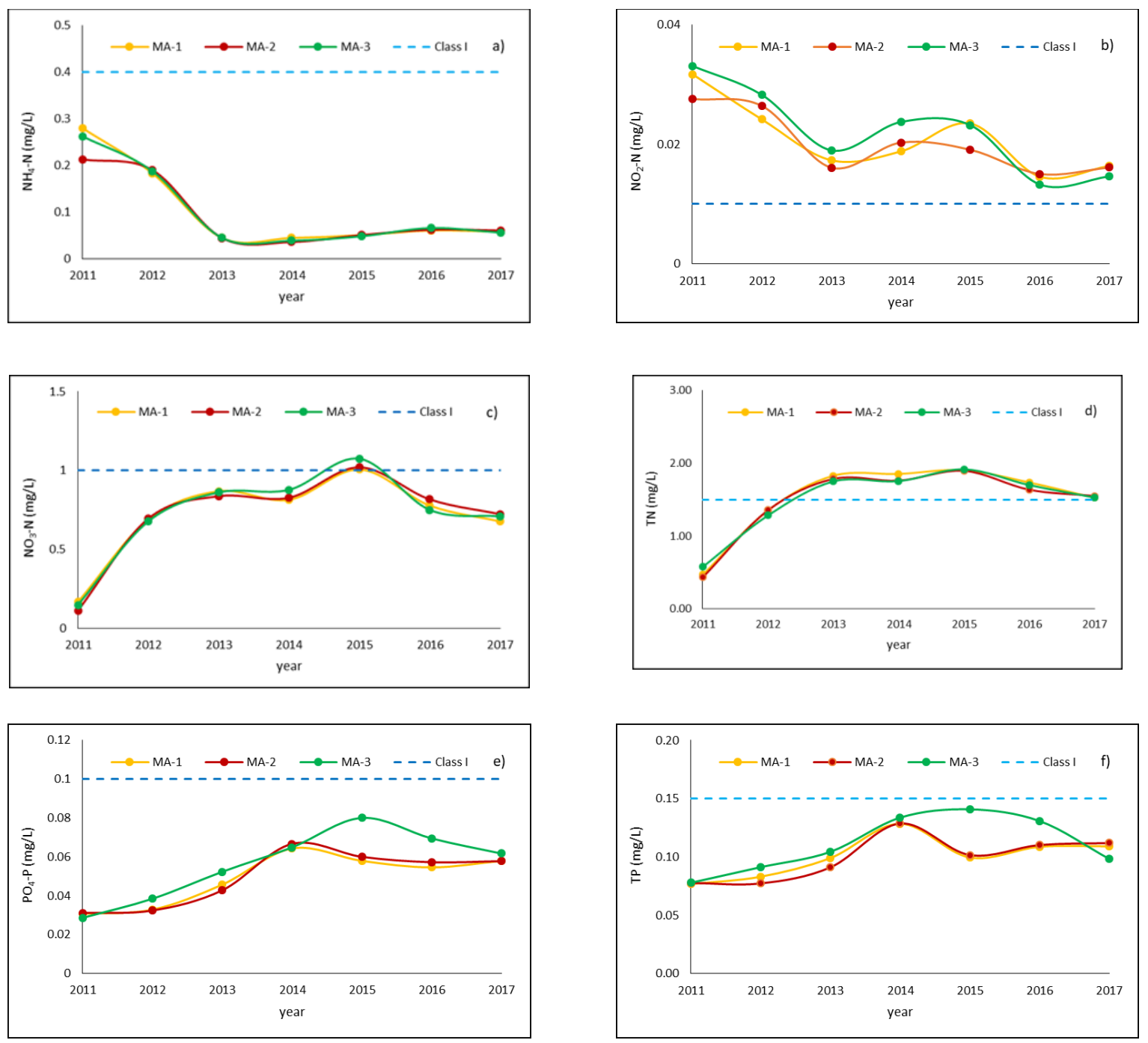

Figure 4. Spatio-temporal variations of monitored parameters:

a) $\mathrm{NH}_{4}-\mathrm{N}$; b) $\mathrm{NO}_{2}-\mathrm{N}$; c) $\mathrm{NO}_{3}-\mathrm{N}$; d) $\mathrm{TN}$; e) $\mathrm{PO}_{4}-\mathrm{P}$; f) $\mathrm{TP}$ 
The loading with nutrients of Danube River is influenced mainly in spring and early summer due to high variations in flow, which are influenced by snow melt and high precipitation fall, respectively. In section MA-2 there were practically the works for improvement of the navigation conditions, also were influenced the value of $\mathrm{Chl}$ ' $\mathrm{a}$ ' and $\mathrm{pH}$ which have slightly higher values in this section than in the other monitored sections (figure 5-a). TN/TP report shows values greater than 10 , which indicates a favourable growth potential of eutrophication. Higher values of TN/TP report are in MA-1 and MA-2 areas, where it is probably due to higher water flow that favours the erosion process and the nitrogen and phosphorus forms results from leaching phenomena from soil (figure 5-c). From figure 5-d, the results show that in the monitored areas the hydrological regime of the Danube is relatively uniform, with the exception of section MA-2 where very low values for water flow are observed.
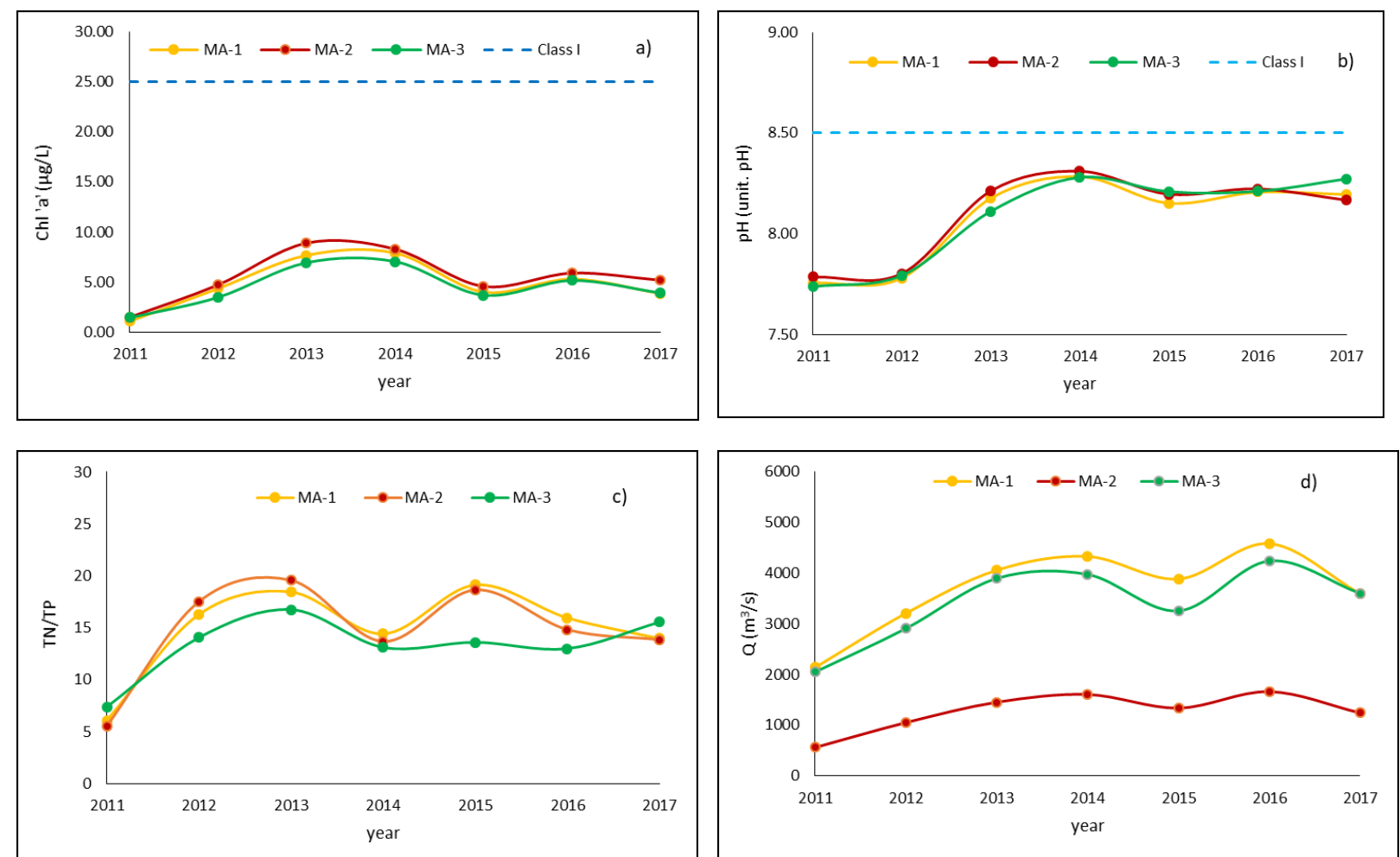

Figure 5. Spatio-temporal variations of monitored parameters:a) $\mathrm{Chl}$ ' $a$ '; b) pH; c) TN/TP; d) Q

For to establish the distribution of monitored parameters, the statistical distribution of the data was compared to an equivalent normal distribution, with an average confidence level of $95 \%$. Histograms for concentration of parameters are shown in figure 6 .
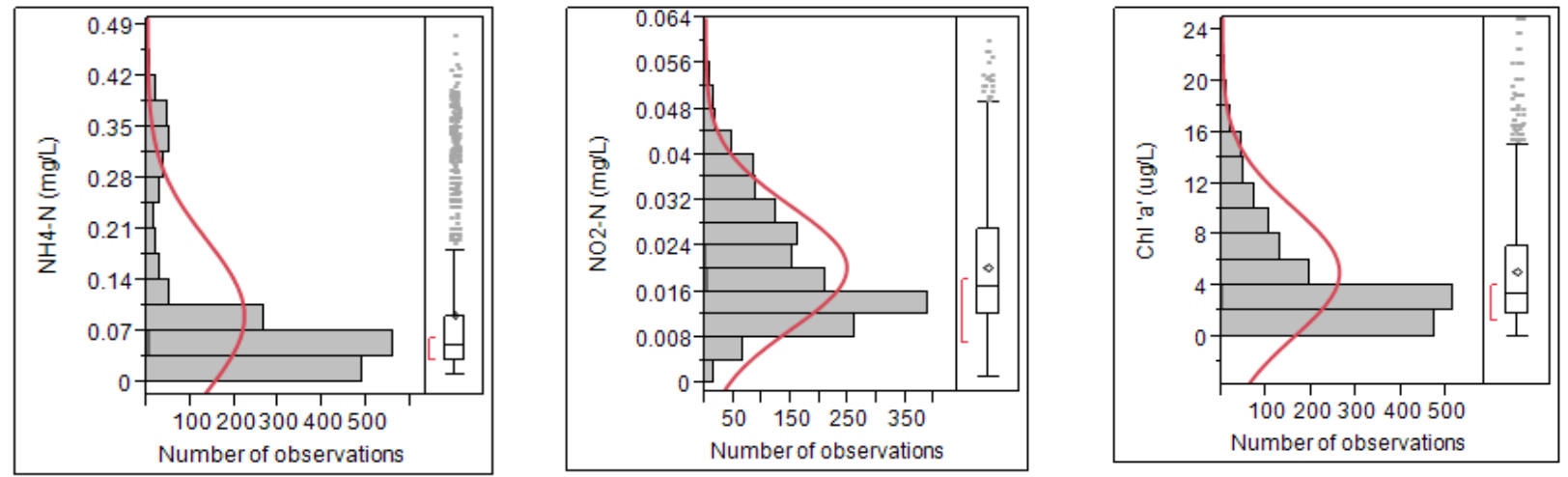

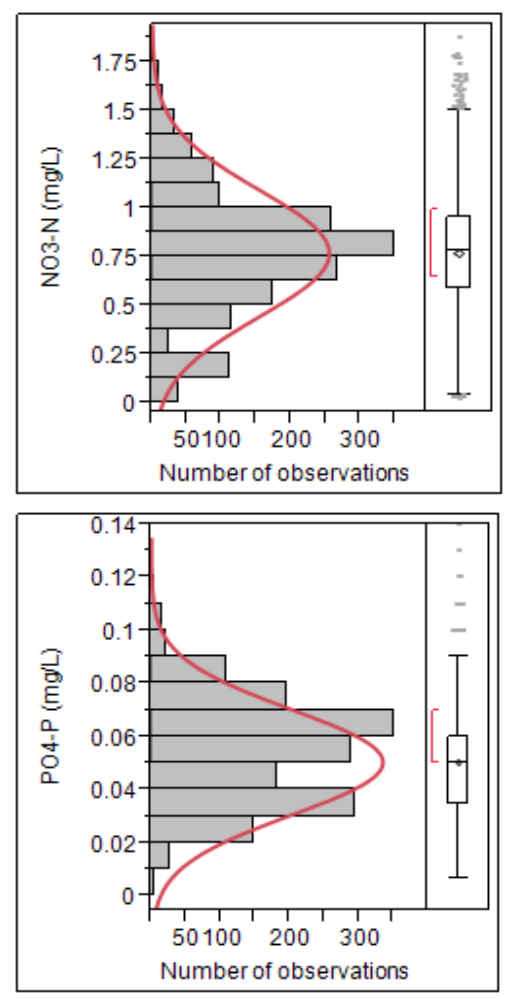
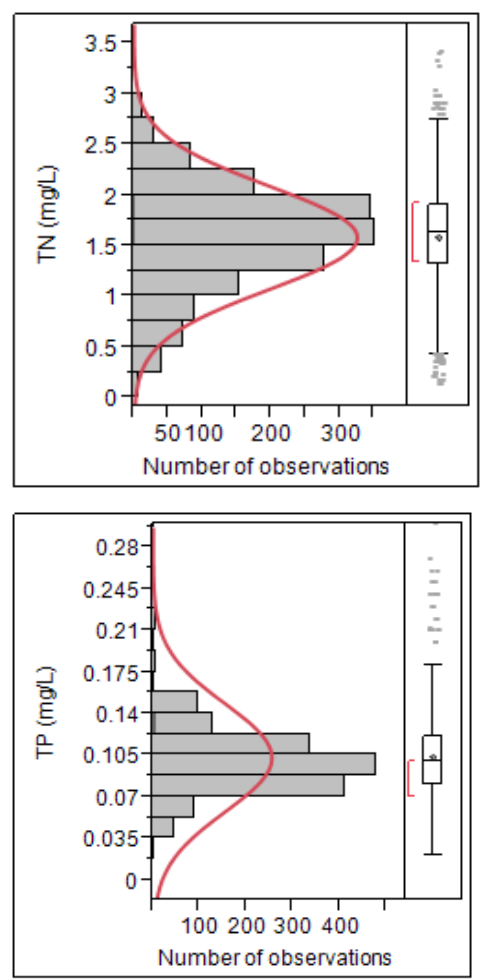
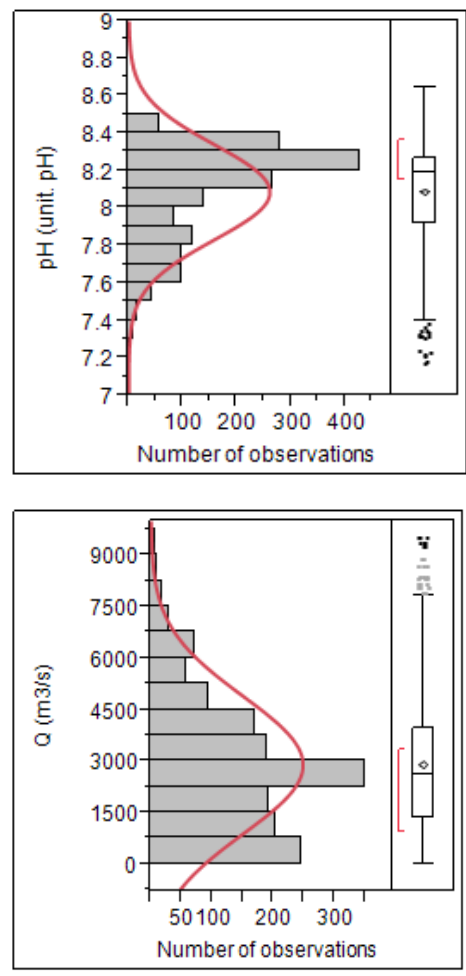

Figure 6. Histograms of elements concentrations

The assessment of histogram confirmed that the original data sets for the analysed parameters are normally distributed. Over all, the assessed ecosystem is not severely affected by the presence of nutrients in water, resulting also in the heterogeneous distribution of the elements represented in histograms.

From the temporal evolution, the monitored indicators show higher values over the period 20132015 , which is probably due to upstream nutrient loads and the more abundant rainfall that occurred during from that period.

The application of multivariate statistical methods can provide logistical support for the detection of pollution in case of accidental contaminations.

\section{Conclusions}

The eutrophication status of the Lower Danube waters, evaluated during the period 2011-2017 in the Calarasi-Braila area ( $\mathrm{km} 375$ - km 175), where works were done to improve navigation conditions, is presented in this paper. The nutrients content was corelated with other water quality parameters, taking also into account the waters hydrological regime. Using statistical methods for the monitored water parameters it was possible to reveal that there have been exceedances of normal values according to the national legislation in force. Moreover, multivariate statistics allowed to identify the main factors that underlies the variability of water quality data and to provide a new insight in interpreting environmental quality based on large database of measurement results. By applying PCA method, 4 principal components were identified with a combine share of approximately $76 \%$ of the original variability, and the statistical distribution of parameters represented by histograms confirmed that the original data sets are normally distributed. Three main groups were identified from the cluster analysis, highlighting the correlation between nutrients, Chl ' $\mathrm{a}$ ' and water flow. Three main groups were identified from the cluster analysis, highlighting the correlation between nutrients, Chl ' $\mathrm{a}$ ' and water flow.

From the spatio-temporal representation of the monitored parameters, the following quality items result: $\mathrm{NH}_{4}-\mathrm{N}, \mathrm{NO}_{3}-\mathrm{N}$ and $\mathrm{TN}$ fall into classes I-II, $\mathrm{NO}_{2}-\mathrm{N}$ fall in class I-III, $\mathrm{PO}_{4}-\mathrm{P}$ and TP fall in class 
I, Chl 'a' fall into class I and $\mathrm{pH}$ also fall into class I. Lower water flow rates have been recorded in the section MA-2 where navigation conditions have been improved throughout the monitored period.

The obtained results can be useful as a comparison base for authorities with competences in environmental protection for identifying environmental pollution and acting accordingly to decrease it.

Acknowledgements: This work used raw data was obtained from the POST contract Monitoring of Environmental Impact of the Works for Improvement of the Navigation Conditions on the Danube

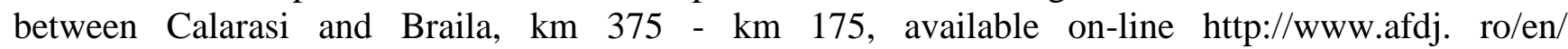
content/romomed). The authors would like to thank the management and employees of National Institute for Research and Development in Environmental Protection for their valuable assistance and suggestions. Violeta-Monica Radu's contribution was partially financed by the Operational Programme Human Capital of the Ministry of European Funds through the Financial Agreement 51668/09.07.2019, SMIS code 124705.

\section{References}

1. POSTOLACHE, C., DEACONU (STANESCU), L.F., BOTEZ, F., Rev. Chim. (Bucharest), 62 , no. $12,2011,1219$.

2. LEVI, L., CVETKOVIC, V., DESTOUNI, G., Science of the Total Environment, 610-611, 2018, p. 482.

3. HORA ALVES, J. P., FONSECA, L.C., AlVES CHIELlE, R., BARRETO MACEDO, L.C., Brazilian Journal of Water Resources, 23, no. 27, 2018, p. 1.

4. SABATER, S., BREgOli, F., ACUNA, V., BARCElO, D., ElOSEGI, A., GINEBREDA, A., MARCE, R., MUNOZ, I., SABATER-LIESA, L., FERREIRA, V., Scientific Reports, 8, no. 11462, 2018, p. 1.

5. MATEI, M., LASLO, L., CIOBOTARU, N., MUSAT, C., BOBOC, M., RAISCHI, M., DEAK, Gy., International Journal of Environmental Science, 1, 2016, p. 265.

6. DODDS, W.K., SMITH, V.H., Inland Waters, 6, 2016, p. 155.

7. SAVIC, A., PESIC, V., DORDEVIC, M., RANDELOVIC, V., JUSKOVIC, M., ANDRZEJ, G., NORTH-WESTERN JOURNAL OF ZOOLOGY, 14, no. 2, 2018, p. 226.

8. BOWMER, K.H., Resources, 2, 2013, p. 439.

9. DEAK, Gy., DAESCU, V., HOLBAN, E., MARINESCU, P., TANASE, G., CSERGO, R., DAESCU, A.I., GAMAN, S., J Environ Prot Ecol., 16, 2015, p. 304.

10. SPIRIDON, C., TEODOROF, L., BURADA, A., DESPINA, C., SECELEANU-ODOR, D., TUDOR, I.M., IBRAM, O., GEORGESCU, L.P., TOPA, C.M., NEGREA, B.M., TUDOR, M., AACL Bioflux, 11, no. 6, 2018, p. 1882.

11. Illinois Nutrient Science Advisory Committee, Recommendations for numeric nutrient criteria and eutrophication standards for Illinois streams and rivers, 2018.

12. MARCU, E., DEAK, Gy., CIOBOTARU, I.E., IVANOV, A.A., IONESCU, P., TOCIU, C., DIACU, E., Rev. Chim., (68), no. 12, 2017, 2744.

13. BENNETT, M.G., SCHOFIELD, K.A., LEE, S.S., NORTON, S.B., Environ Evid, 6, no. 18, 2017, p. 1.

14. RATHORE, S.S., CHANDRAVANSHI, P., CHANDRAVANSHI, A., JAISWAL, K., Journal of Agriculture and Veterinary Science, 9, no. 10, 2016, p. 89.

15. ***Congressional Research Service, Freshwater Harmful Algal Blooms: Causes, Challenges, and Policy Considerations, 2018.

16. CIRTINA, D., CAPATINA, C., Rev. Chim., 67, (12), 2016, 2429.

17. DANALACHE, T.M., BADILITA, A.M., DEAK, GY., HOLBAN, E., POPESCU, I., DAESCU, A. RAISCHI, M.C., GHITA, G., NICOLAE, C.G., DIACONESCU, S., AACL Bioflux, 10, no. 5, 2017, p. 1011. 
18. TOROK, L., TOROK, Z., CARSTEA, E.M., SAVASTRU, D., Water Environment Research, 89, no. 1,2017 , p. 86.

19. J., PETRE, T., GAlAON, V.I., IANCU, G.G., VASILE, E., STANESCU, L.F., PASCU, M., SIMION, L., CRUCERU, Rev. Chim., 67, (8), 2016, 1436.

20.***ICPDR, Reducing nutrient pollution, challenges in agriculture, 2013. Available from: https://www.icpdr.org/main/sites/default/files/nodes/documents/bp-nutrients-final.pdf.

21. CIOBOTARU, I.E., MARCU, E., CIMPOERU, C., SAVIN, I., IVANOV, A.A., AES Bioflux, 9, no. 1,2017 , p. 6 .

22. ICPDR, The Danube River Basin District Management Plan, Part A-Basin-wide overview, update 2015, ICPDR-International Commission for the Protection of the Danube [Internet]. 16 December 2015. Available from: https://www.icpdr.org/main/management-plans-danube-river-basin-published.

23. CRETESCU, I., KOVACS, Z., CIMPEANU, S.M., Monitoring of Surface Water Status in the Lower Danube Basin, Chapter 10, INTECH, 2016, p. 205.

24. COZZI, S., IBANEZ, C., LAZAR, L., RAIMBAULT, P., GIANI, M., Water, 11, no. 1, 2019, p. 1.

25. WOINAROSCHY, A., SINGUREANU, C., Rev. Chim., 68, (12), 2017, 2812.

26. MALAGO, A., BOURAOUI, F., VIGIAK, O., GRIZZETTI, B., PASTORI, M., Science of the Total Environment, 603-604, 2017, p. 196.

27. POPOVICI, M., Hdb Env Chem, 39, 2016, p. 23.

28. TIMOFTI, M., ITICESCU, C., ARSENI, M., CALMUC, M., CALMUC, V.A., GEORGESCU, L.P., International Journal of Bioscience, Biochemistry and Bioinformatics, 9, no. 1, 2019, p. 65.

29. ***POS-T Project Monitoring of Environmental Impact of the Works for Improvement of the Navigation Conditions on the Danube between Calarasi and Braila, km 375 - km 175. Available from: http://www.afdj.ro/en/content/romomed.

30. RADU, V.-M., DIACU, E., IONESCU, P., IVANOV, A.A., U.P.B. Sci. Bull., Series B, 79, no. 3, 2017 , p. 2.

31. ***Ministerial Order No. 161, (2006), Approving the Norms on surface water quality classification to determine the ecological status of water bodies.

32. *** Directive 2000/60/EC of the European Parliament and of the Council establishing a framework for the Community action in the field of water policy.

$\overline{\text { Manuscript received: } 16.07 .2019}$ 